\title{
JoAn Segal to be next executive director of ACRL
}

JoAn S. Segal, currently executive director of the Bibliographic Center for Research (BCR) in Denver, will become ACRL executive director on September 1,1984 . She succeeds Julie Carroll Virgo, who leaves ACRL on June 30 to become vice-president of the Carroll Group, a management consulting firm.

Segal has been at BCR since October 1978, first as a resource sharing program manager and later as interim executive director. She was named executive direc-

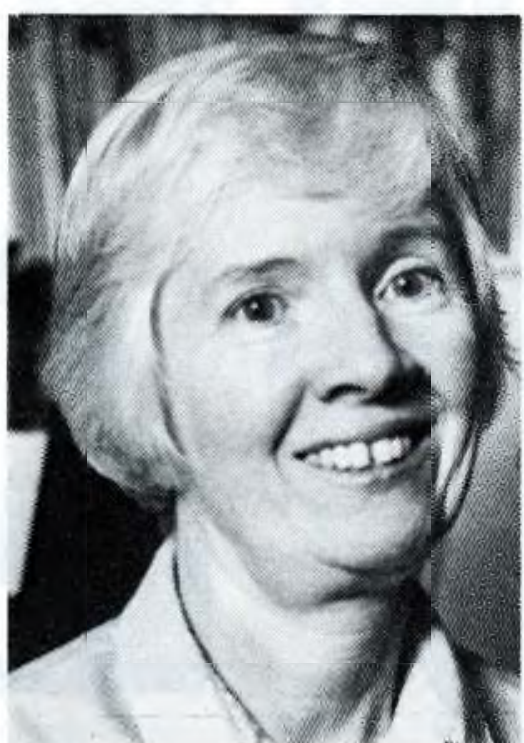

JoAn S. Segal tor in 1981. In that position she was in charge of operations and carried out planning activities for the Center. BCR is a regional cooperative of libraries offering products and services which help its members provide better library and information service.

After earning a B.A. degree in library service from Rutgers University, Segal went on to earn an MLS from Columbia University in 1955 and a Ph.D. in communication from the University of Colorado in 1978. The title of her Ph.D. dissertation, "Group Development in Theater Casts," reveals her still active interest in drama.

Dr. Segal has worked in many different library settings ever since she started work as a library assistant at the New Jersey College of Agriculture Library in 1949. She has also held professional positions at the U.S. Department of Agriculture Library, Carter Products, Columbia University Teachers College, Bergen Junior College, the Columbia University College of Physicians and Sur- geons, and the Institute of Mathematical Sciences.

From 1970 to 1976 she was librarian at the Western Interstate Commission for Higher Education in Boulder, Colorado, where she established a cataloging and classification system for the document collection and established a collection on grants information. While working on her Ph.D., she was a graduate teaching assistant for several communications courses at the University of Colorado and did consulting work for a health planning organization in Denver.

In 1976-1978 Segal was a consultant on the development of a handbook on terminology for classifying and describing the learning activities of adults, published by the National Center for Higher Education Management Systems in Boulder.

She has written numerous articles for such periodicals as Library Journal, Resource Sharing and Library Networks, Education Libraries, and Colorado Libraries, and has co-authored several monographs, including Western States Resource Sharing Directory (1980), a Library Manual for Health Planning Agencies (1978), and a Library Manual in Lifelong Learning (1978).

Last October she taught a one-credit course in networking at the University of Iowa Graduate Library School. She has also conducted microcomputer workshops and telecommunications seminars at BCR.

Segal said she was excited about coming to ACRL and "learning a new professionassociation management. This extremely attractive opportunity to be active at a national level will be a challenge," she said, "but I feel supported by the many academic librarians in the BCR region who have become my friends."

The ACRL officers, staff, and membership extend an enthusiastic welcome to Dr. Segal.

\section{Z39 changes its name}

In February the 45 voting members of the American National Standards Committee (Z39) voted to rename their association the National Information Standards Organization (Z39). The group will continue its program of national and international standards development first set in 1939 when it was created by representatives of ALA, the American Association of Law Libraries, the Medical Library Association, and the Special Libraries Association.

When Z39 was incorporated as a not-for-profit educational association in early 1983, the officers voted to consider a new name that would clearly describe the organization's mission to develop voluntary technical standards for the information community. A national name contest was held to solicit new names. The winning entry was submitted by Ron Buchan, a lexicographer with the National Aeronautics and Space Administration.

NISO (Z39) is located at the U.S. Department of Commerce, National Bureau of Standards, Administration Building, Room E-106, Washington, DC 20234; (301) 921-3241. 


\section{A LIBRARIAN'S DREAM BECAME REALITY...}
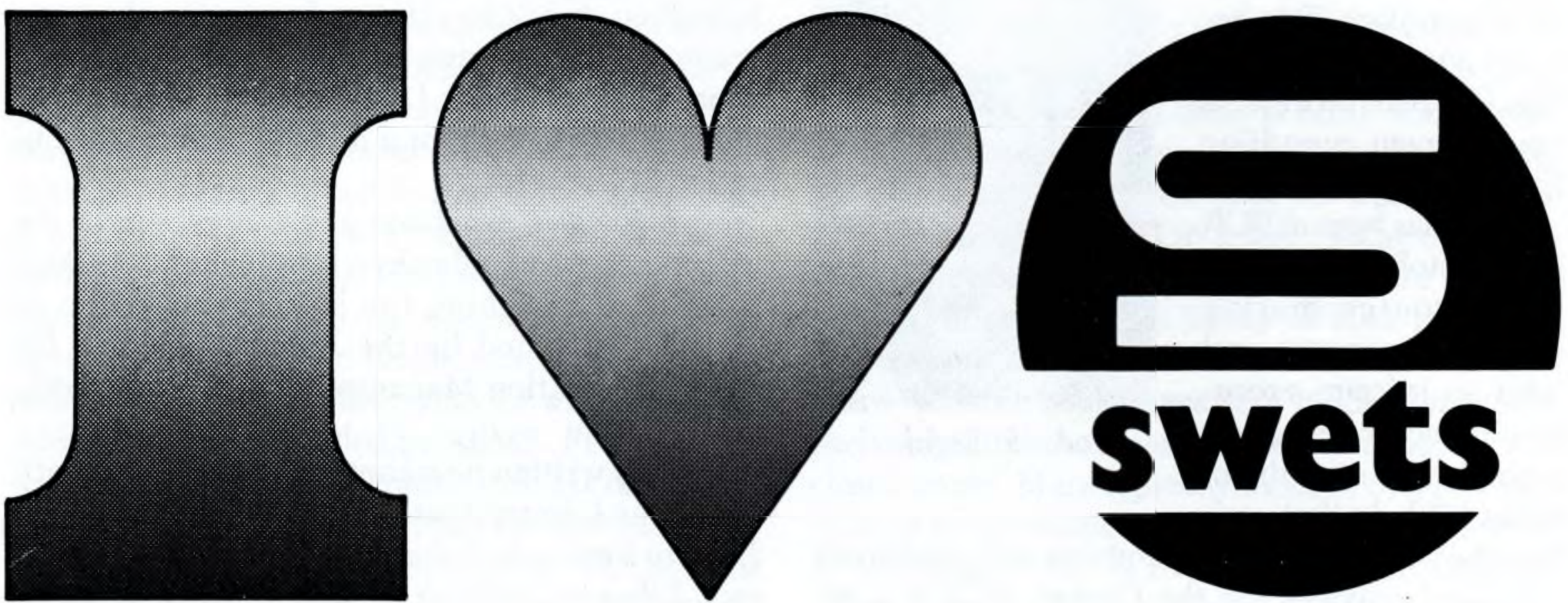

... and there was plenty of time for the interesting aspects of library work ... the new year started with far less "European headache".

Notorious trouble titles arrived (air freighted) at regular intervals, securely packed and always accompanied by a packing slip with key numbers exactly according to the library's instructions (and of vital importance to the administration).

And ... believe it or not, an occasional missing issue (if any) had already been claimed with the publisher before it was noticed in the library ...

There was much more she could not remember after she woke up ... until she spotted the brochure she read the night before...

You are invited to share her dream. Ask for the same brochure, giving full details of the Swets FAST $^{\oplus}$ system, an online system of controlled serial distribution.

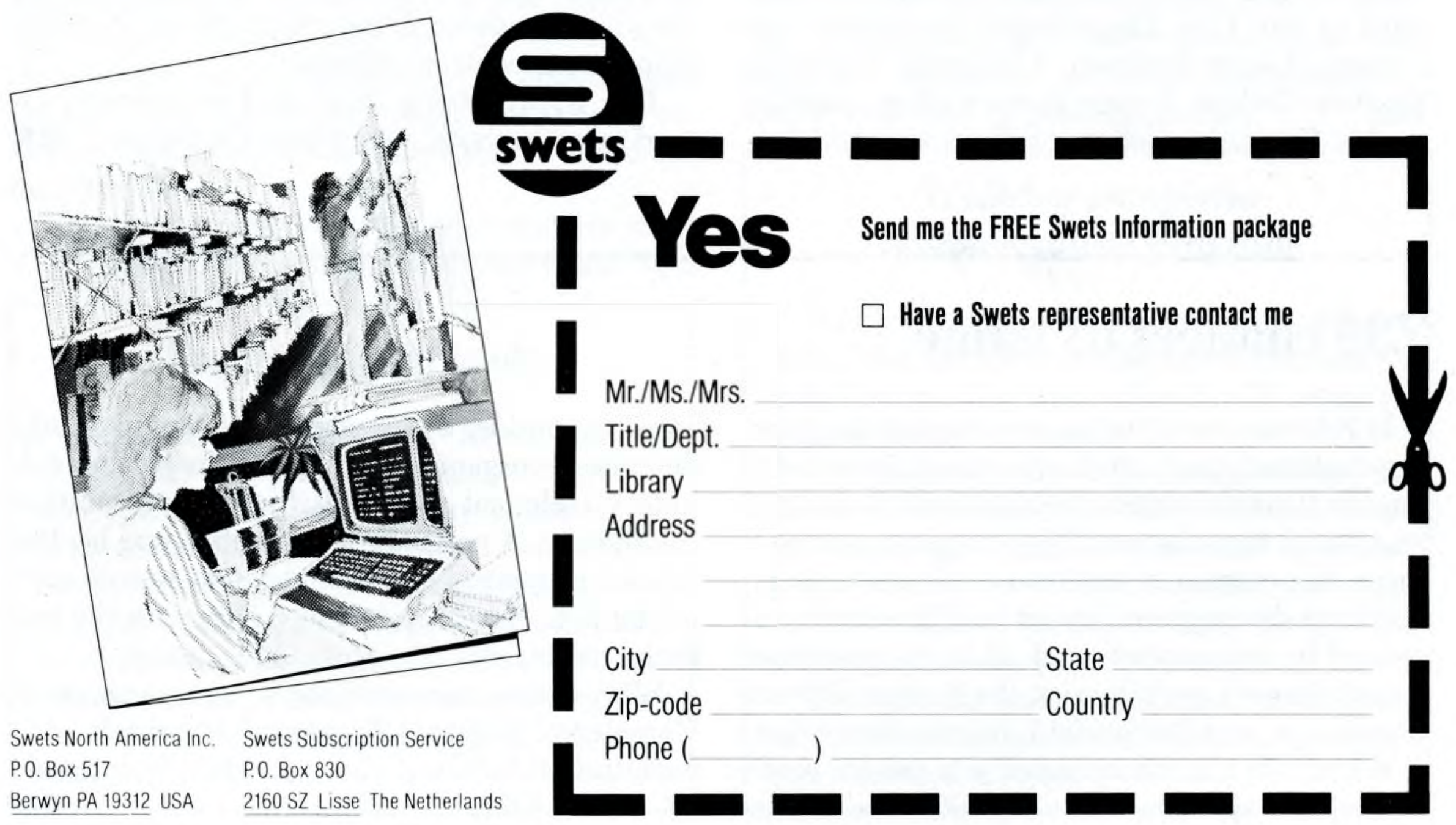

